Journal of Physical Science, Vol. 28(2), 143-159, 2017

\title{
Hydrogen and Oxygen Stable Isotopes of Palm Oil Mill Effluent in Surface Water and Groundwater Water
}

\author{
Roslanzairi Mostapa, ${ }^{1 *}$ Mohamad Shaiful Md. Yusuff, ${ }^{2}$ Widad Fadhlullah and \\ M. I. Syakir ${ }^{3 * *}$ \\ ${ }^{1}$ Environmental Tracer Application Group (ETAG), Agensi Nuklear Malaysia, \\ 43600 Kajang, Selangor, Malaysia \\ ${ }^{2}$ School of Industrial Technology, Universiti Sains Malaysia, \\ 11800 USM Pulau Pinang, Malaysia \\ ${ }^{3}$ Centre for Global Sustainability Studies (CGSS), Universiti Sains Malaysia, \\ 11800 USM Pulau Pinang, Malaysia \\ Corresponding authors: roslanzairi@nuclearmalaysia.gov.my* \\ misyakir@usm.my**
}

Published online: 15 August 2017

To cite this article: Mostapa, R. et al. (2017). Hydrogen and oxygen stable isotopes of palm oil mill effluent in surface water and groundwater water. J. Phys. Sci., 28(2), 143-159, https://doi.org/10.21315/jps2017.28.2.10

To link to this article: https://doi.org/10.21315/jps2017.28.2.10

\begin{abstract}
Stable isotope technique has been applied in this study to determine whether the isotopic ratio values of ${ }^{2} \mathrm{H}$ and ${ }^{18} \mathrm{O}$ could be used distinctly to identify palm oil mill effluent (POME) as a source of surface water and groundwater contamination in the study area. In this project, surface water samples from upstream and downstream of palm oil effluent mill-related furrow and river groundwater samples within the study site, along with POME samples, were analysed to study the applicability of the stable isotope ratios as a tool for evaluating the characteristics of POME and its impact to the environment. The highly enriched isotopic values of POME and treated POME associated with oil palm production processes and treatment of the POME in the Effluent Treatment Plant (ETP) provide unique distinct isotopic composition for the POME and treated POME-impacted waters resulted from the mixing process either in the surface water or groundwater.
\end{abstract}

Keywords: Palm oil mill effluent, stable isotope, surface water, groundwater, POME

(C) Penerbit Universiti Sains Malaysia, 2017. This work is licensed under the terms of the Creative Commons Attribution (CC BY) (http://creativecommons.org/licenses/by/4.0/). 


\section{INTRODUCTION}

Oil palm is the world's most efficient oilseed crop. A single hectare of oil palm plantation is able to produce up to ten times more oil (Figure 1) than other leading oilseed crops such as soybean, rapeseed and sunflower. ${ }^{3}$

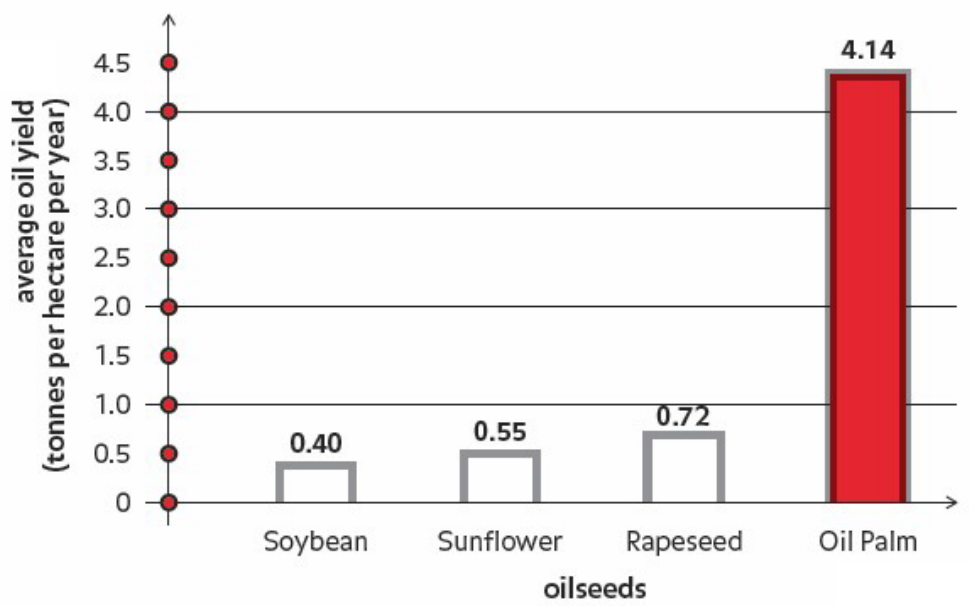

Figure 1: Oil palm efficiency vs. other major oil crops.

Among the ten major oilseeds, oil palm accounts for only 5.3\% of global land use in terms of cultivation but 31.3\% of global oils and fats output in 2011 (Figure 2). Palm oil is one of the 17 major oils and fats produced globally. Among these, palm oil was the most-consumed oil in 2011, with a total of 49.05 million tonnes (Figure 3 ) reaching three billion people in 150 countries. China is the largest consumer of oils and fats, followed by the EU, India and the United States. ${ }^{3}$ 


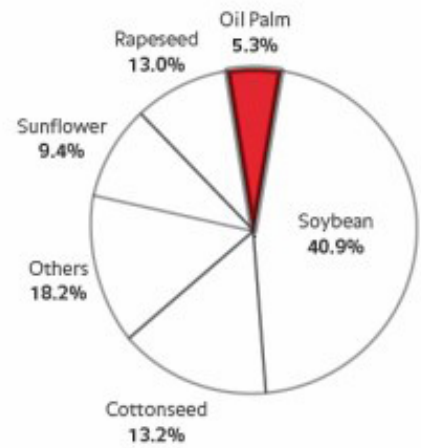

10 Major Oilseeds : Area in 2011 (Total $=253.9$ mil hectares)

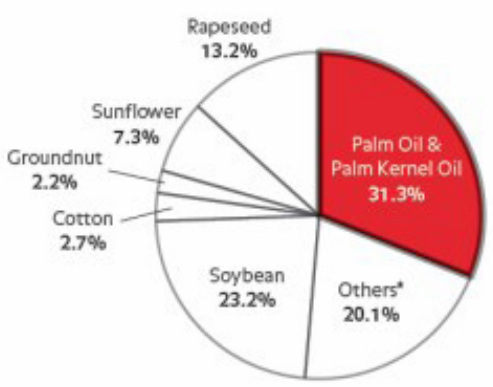

Global Production of Oils and Fats in 2011 (Total $=179.38$ mil tonnes)

(b)

Figure 2: (a) Comparison between oils production for ten major oilseeds and (b) global land use.

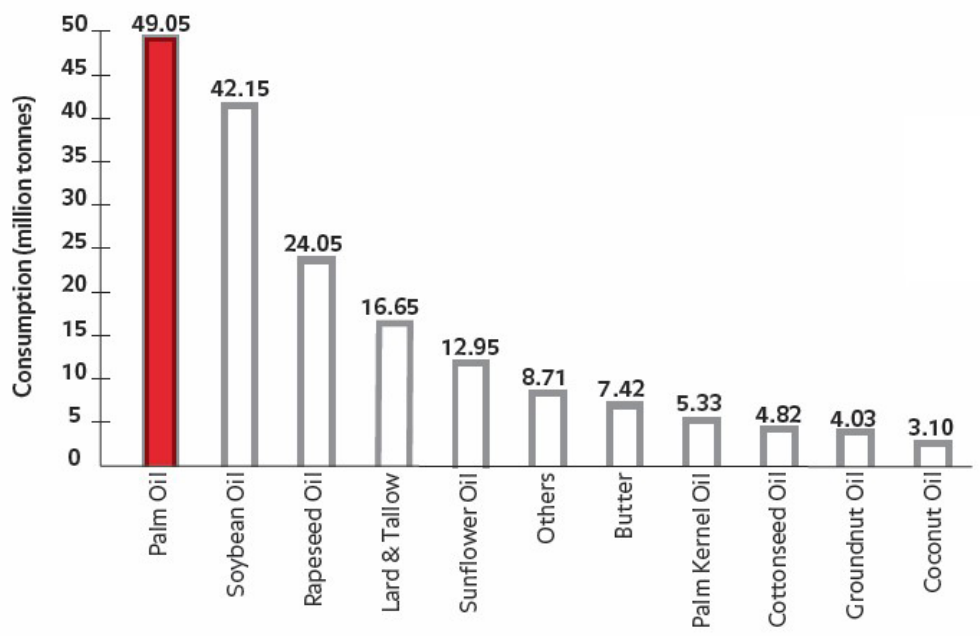

Figure 3: World consumption of oils and fats in 2011 (total $=178.26$ million tonnes).

Due to these impressive statistics, palm oil production has become a major industry in Malaysia, which now ranks as one of the largest producers in the world. 
Malaysia and Indonesia combined produce about $85 \%$ of the world's palm oil. Other producer countries include Thailand, Columbia and Nigeria. As one of the world's main exporters and producers of palm oil, the total oil palm planted area in Malaysia reached $4.98 \mathrm{Mha}$ as of September 2011, covering approximately $73 \%$ of the agricultural land and $14.3 \%$ of total land area. ${ }^{7}$ In Malaysia, the total production of crude palm oil (CPO) in 2011 increased by $11.3 \%$ to a record high of 18.91 million tonnes. ${ }^{5}$ Although Malaysian oil palm accounted for just 1.97\% (approx. 5 million hectares) of the total 253.9 million hectares planted with oilseed crops globally, it supplied a total of $12.7 \%$ (18.91 million tonnes) of global vegetable oils and fats output in 2011. From the total 18.91 million tonnes of Malaysian palm oil produced, 17.99 million tonnes contributed to the total global trade of oils and fats in 2011, making up $26.2 \%$ of world exports. Due to this high level of production, large amounts of water are required for extracted oil clarification and palm fruit bunch sterilisation. Also, oil palm mill processes require a large quantity of water for operations. Therefore, a huge amount of palm oil mill effluent (POME) is released by the palm oil industries. Around $0.87 \mathrm{~m}^{3} \mathrm{POME}$ is released for each tonne of palm fruit milled in the factory. ${ }^{2}$

In 2008 alone, at least 44 million tonnes of POME were generated in Malaysia. ${ }^{12}$ This was an increase compared to 2004, when more than 40 million tonnes of POME were generated from 372 mills in Malaysia. ${ }^{11}$ This wastewater is composed of a viscous, brownish liquid containing about $95 \%-96 \%$ water, $0.6 \%-0.7 \%$ oil, and $4 \%-5 \%$ total solids (including $2 \%-4 \%$ suspended solids). It is acidic (pH $4-5$ ), with a high temperature $\left(80^{\circ} \mathrm{C}-90^{\circ} \mathrm{C}\right)$, high organic $\mathrm{COD}(50,000 \mathrm{mg} / \mathrm{l})$, and high $\operatorname{BOD}(25,000 \mathrm{mg} / \mathrm{l})$. It is 100 times more recalcitrant than domestic wastewater. ${ }^{10}$ A summary of raw POME characteristics from various studies is provided in Table 1. If the effluent is discharged untreated, it may cause significant environmental impact due to its highly soluble chemical materials. 
Conventional techniques are limited because these cannot differentiate pollution of POME, leading to the use of isotope technique in detecting the contamination. Nevertheless, these two techniques must be coupled together because the use of the isotope technique alone could lead to misinterpretation. Previous studies on leachate contamination have demonstrated that the biogeochemical processes within the landfill environment can produce a unique composition for these isotopes and that the stable isotope ratios of $\mathrm{d} 2 \mathrm{H}, \mathrm{d} 18 \mathrm{O}$, and $\mathrm{d} 13 \mathrm{C}$ can be utilised successfully to delineate leachate influence. ${ }^{1}$ However, no study has yet to investigate the POME influence on the surface and groundwater using stable isotope of $13 \mathrm{C}$ in Malaysia. Mohd Tadza et al. used stable isotopes of $2 \mathrm{H}$ and $18 \mathrm{O}$ to study the interconnection between leachate-groundwater-surface waters and tritium to determine the age (the water is mixed of sub-modern and modern groundwater) of the water samples at the same landfill site. ${ }^{6}$ Therefore, the main objective of this study is to evaluate the ability of stable isotope ratios of $\mathrm{d} 2 \mathrm{H}$ and $\mathrm{d} 18 \mathrm{O}$ in distinguishing the water samples analysed and generate a potential tool in detecting POME contamination in surface and groundwater. In doing so, a clearer picture of the situation of the water bodies system may be identified. 


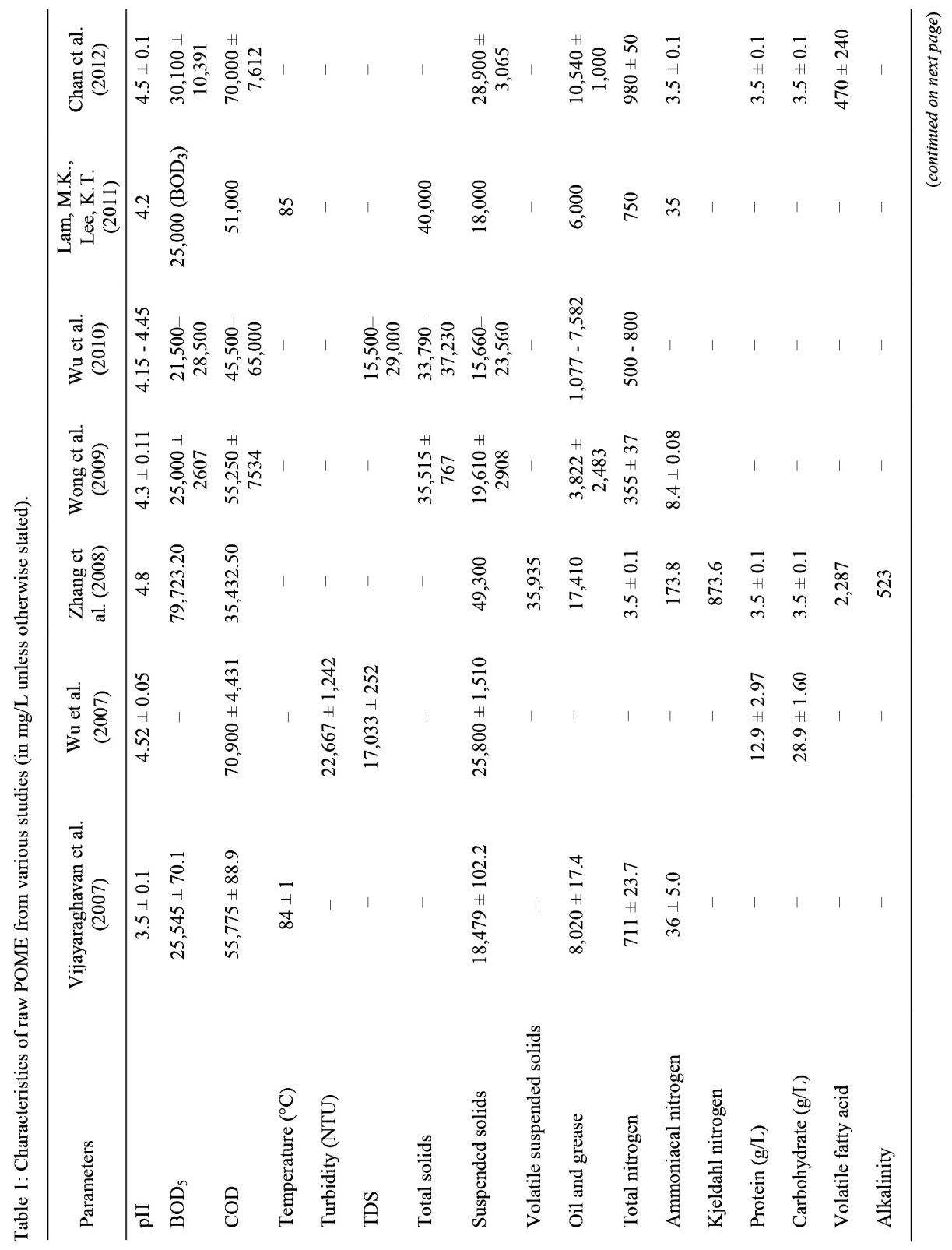




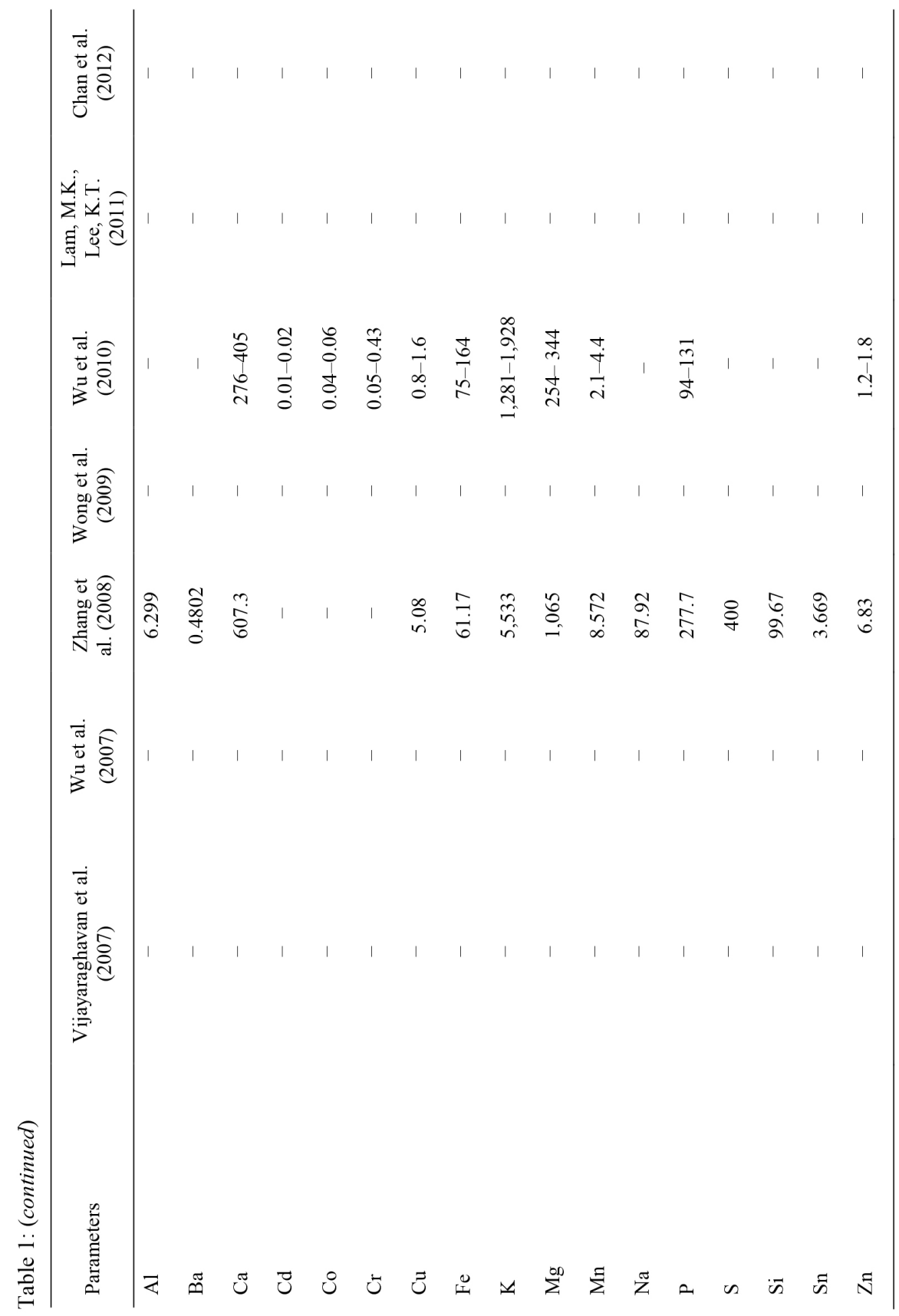




\section{EXPERIMENTAL}

\subsection{Study Area}

The study area was conducted at a palm oil mill in Perak, Peninsular Malaysia (Figure 4). This palm oil mill is located in the northern region of Peninsular Malaysia. The palm oil mill has a mill capacity of 30 metric tonnes/hour $(\mathrm{mt} / \mathrm{hr})$ and the annual tonnages production of crude palm oil (CPO) is approximately 35,000 tonnes.

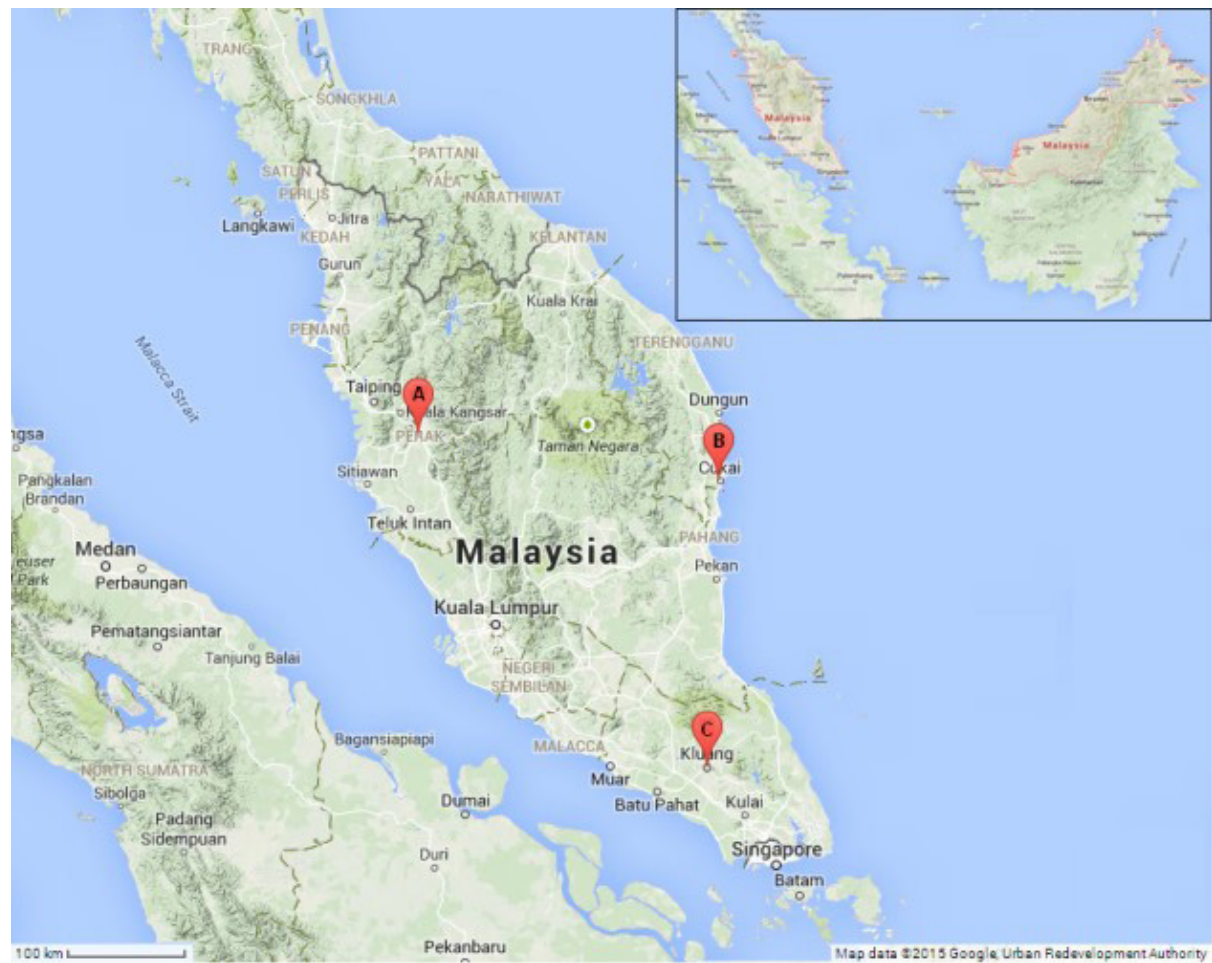

Figure 4: Study area map.

\subsection{Geophysical Technique}

Groundwater contamination investigation at the study sites began with a minimum intrusive technique known as the geophysical technique with the purpose of initial field screening method. This technique is less expensive than other, more intrusive techniques such as soil borings, test pits and well monitoring. One of the important 
categories of geophysical technique is electrical resistivity imaging (ERI). ERI is a geophysical survey used at the surface to provide a rapid reconnaissance of the hydrogeological conditions such as depth to bedrock, degree of weathering, and presence of clay lenses or fractured zones. In additional, ERI technique also can be used to detect and map inorganic contaminant plumes, obtain the flow direction, and estimate the concentration gradient. The results obtained from the ERI will be analysed and used to identify potential borehole drilling sites. ERI was performed with the multi-channel data acquisition ABEM LUND Imaging System consisting of a Terrameter SAS 4000 system, LUND electrode selector system (ES464), multi-core cable, and electrodes (Figure 5).

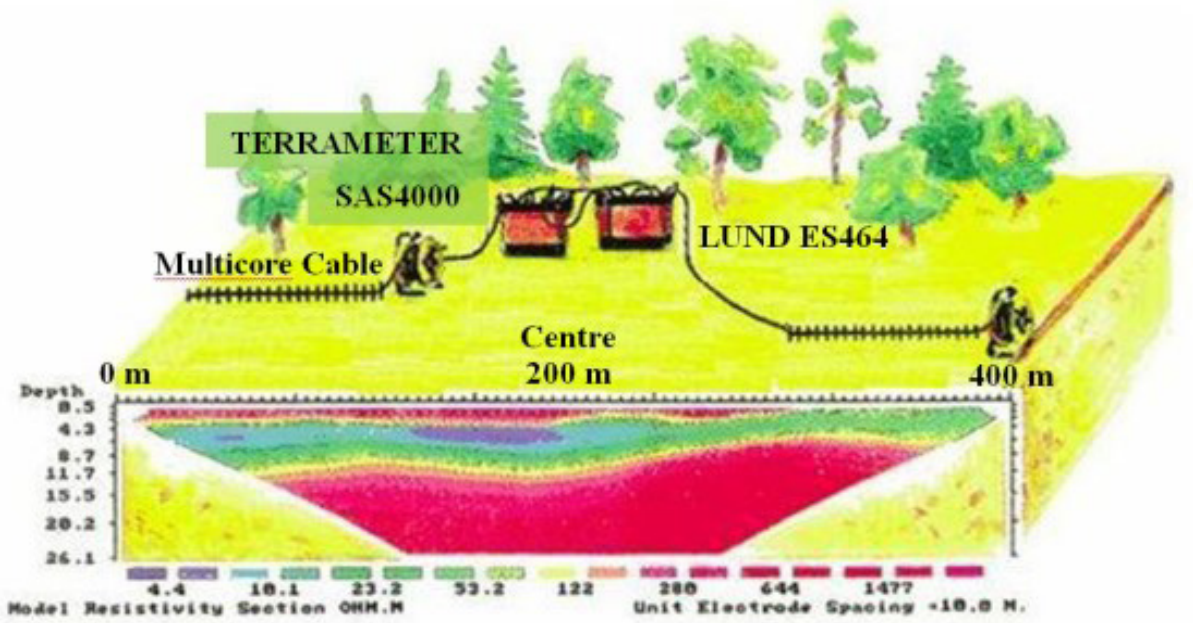

Figure 5: ABEM LUND Imaging System arrangements at site.

In this study, two ERI lines, each $400 \mathrm{~m}$ long were laid at the study site. For this $400 \mathrm{~m}$ survey line, two multicore cables (200 $\mathrm{m}$ each) were used. These survey lines were positioned at the upgradient (higher topographic area) and downgradient (lower topographic area) of the Effluent Treatment Plant (ETP), as normally groundwater will flow from higher level area towards the lower level area. Coordinates of each line are shown in Table 2. The upgradient and downgradient lines are stated as Line A and Line B, respectively. The electrode spacing for ERI survey was set at $10 \mathrm{~m}$ apart. Such an arrangement provides a resistivity layer output of the subsurface geological information for up to approximately $30 \mathrm{~m}$ below the ground surface. 
Table 2: ERI survey line coordinates.

\begin{tabular}{llll}
\hline Study area & Survey line & Locations & Coordinates \\
\hline & & $0 \mathrm{~m}$ & $04^{\circ} 53^{\prime} 15.9^{\prime \prime} \mathrm{N}, 101^{\circ} 05^{\prime} 21.1^{\prime \prime} \mathrm{E}$ \\
& Line A & $200 \mathrm{~m}$ (centre) & $04^{\circ} 53^{\prime} 22.3^{\prime \prime} \mathrm{N}, 101^{\circ} 05^{\prime} 21.1^{\prime \prime} \mathrm{E}$ \\
Palm oil mill A & & $400 \mathrm{~m}$ & $04^{\circ} 53^{\prime} 28.7^{\prime \prime} \mathrm{N}, 101^{\circ} 05^{\prime} 21.2^{\prime \prime} \mathrm{E}$ \\
& & $0 \mathrm{~m}$ & $04^{\circ} 53^{\prime} 22.0^{\prime \prime} \mathrm{N}, 101^{\circ} 05^{\prime} 35.9^{\prime \prime} \mathrm{E}$ \\
& Line B & $200 \mathrm{~m}$ (centre) & $04^{\circ} 53^{\prime} 25.0^{\prime \prime} \mathrm{N}, 101^{\circ} 05^{\prime} 31.1^{\prime \prime} \mathrm{E}$ \\
& & $400 \mathrm{~m}$ & $04^{\circ} 53^{\prime} 29.3^{\prime \prime} \mathrm{N}, 101^{\circ} 05^{\prime} 28.00^{\prime \prime} \mathrm{E}$ \\
\hline
\end{tabular}

\subsection{Hydrochemical Technique}

The study was carried out for two years, with water sampling conducted three times for each year, beginning in January 2013 (Table 3). The water sampling involved collecting samples from groundwater (monitoring wells and piezometer) and surface water (furrow upstream, meeting point between furrow and river, river upstream and river downstream). The groundwater and surface waters were labelled GW/PZ and SW, respectively. POME samples were taken from the raw POME and treated POME. In this study, raw POME is the POME which came from the mill after the processing of full fruit bunch (FFB) and collected in ponds before being treated in the ETP. While treated POME is the treated raw POME and discharged to the environment. This treated POME which discharged into the furrow will further flows to the river.

A total of 26 water samples were collected from the sampling points from January to April for the two consecutive years. The monitoring wells were purged with three well-casing volumes to remove stagnant water in the well, so that the water being sampled would be stabilised; representative groundwater was thus obtained prior to sampling. ${ }^{13}$ The surface waters were collected using grab sample from the furrow and river.

The sampling for the hydrochemical technique included the in-situ/field measurement of electrical conductivity (EC), $\mathrm{pH}$, temperature, Total Dissolve Solid (TDS) and Dissolve Oxygen (DO) using portable YSI 556 Multi Probe System. The Multi Probe System for in-situ measurements were calibrated with an appropriate buffer solution ( $\mathrm{pH} 7.00)$ before every sampling program.

\subsection{Stable Isotope Technique}

The primary technique used in this research project is the stable isotope technique. The IRMS used for isotopic analysis is a specialised mass spectrometer which produces precise and accurate measurements of variations in the natural isotopic 
abundance of light stable isotopes. If an isotopic signature could be established for POME, then the $\delta^{2} \mathrm{H}$ and $\delta^{18} \mathrm{O}$ stable isotope ratios could be used as indicators to identify POME as contamination sources in a monitored palm oil estate environment.

The collection of water samples for stable isotope technique was conducted simultaneously with the hydrochemical technique. All the samples were measured for $\delta^{2} \mathrm{H}$-water and $\delta^{18} \mathrm{O}-$ water.

$\delta^{2} \mathrm{H}-\mathrm{H}_{2} \mathrm{O}$ and $\delta^{18} \mathrm{O}-\mathrm{H}_{2} \mathrm{O}$ were measured using SERCON GEO 20-20 Continuous Flow Isotope Ratio Mass Spectrometer (CF-IRMS). Samples for $\delta^{2} \mathrm{H}-\mathrm{H}_{2} \mathrm{O}$ and $\delta^{18} \mathrm{O}-\mathrm{H}_{2} \mathrm{O}$ analyses were treated in the SERCON Water Equilibration System (WES) prior to analysis through the IRMS. Only $0.5 \mathrm{ml}$ of water sample in a vial were used for each analysis. The $\delta^{18} \mathrm{O}-\mathrm{H}_{2} \mathrm{O}$ values were measured via equilibration with $\mathrm{CO}_{2}$ at $50^{\circ} \mathrm{C}$ for $8 \mathrm{~h}$, and $\delta^{2} \mathrm{H}-\mathrm{H}_{2} \mathrm{O}$ values were measured via equilibration with $\mathrm{H}_{2}$ and its reaction with the platinum stick catalyst at $50^{\circ} \mathrm{C}$ for $1 \mathrm{~h}$. In the $\delta^{2} \mathrm{H}-\mathrm{H}_{2} \mathrm{O}$ analysis, a platinum catalyst stick was used to accelerate the reaction, and gas exchange equilibrium took place between the introduced pure $\mathrm{H}_{2}$ gas and water vapour. This gas exchange equilibrium caused the water vapour to emit a signature to the introduced pure $\mathrm{H}_{2}$ gas, which represents the isotopic composition of the water before the $\mathrm{H}_{2}$ gas is analysed by the IRMS (Figure 6).

It is to be noted that a sample preparation unit for the analysis of water samples for hydrogen and oxygen isotope ratios is water equilibration system (WES), which consists of controlled temperature heating block. ${ }^{9}$ 


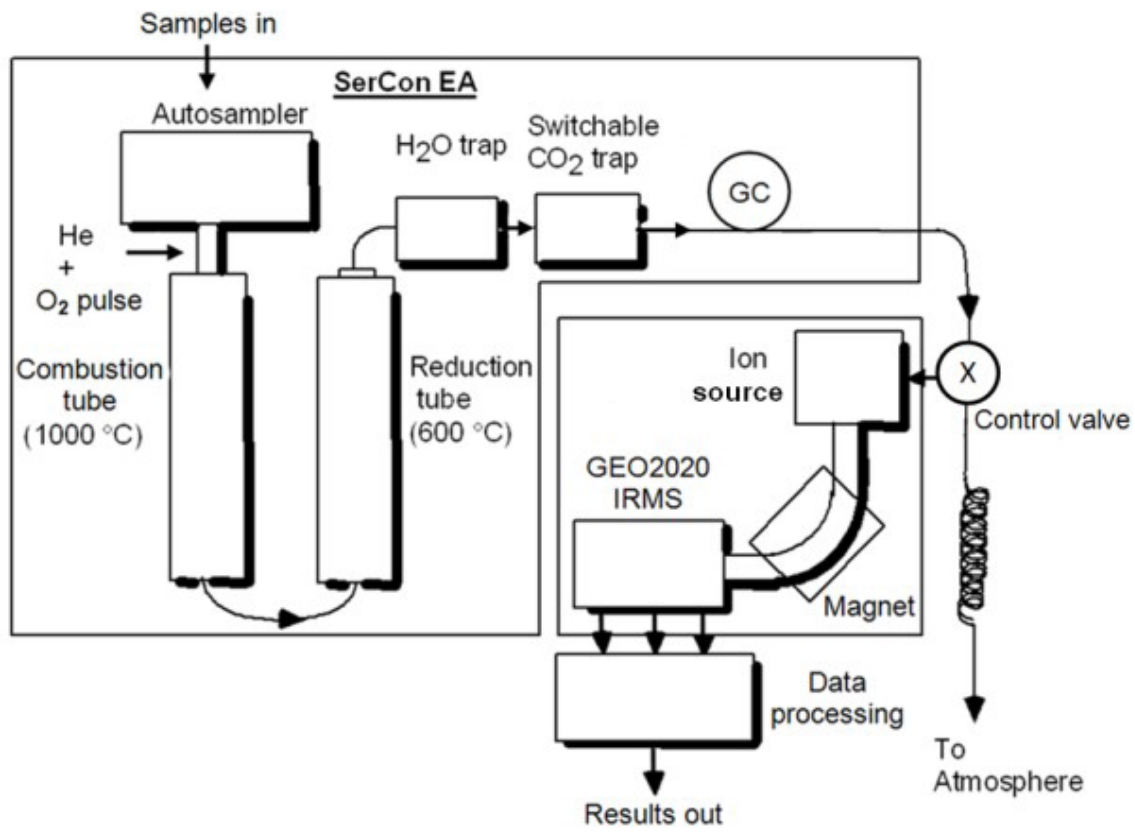

Figure 6: Schematic diagram of an elemental analyser (EA) in series with an IRMS for the analysis of carbon isotope ratios (SERCON, 2007).

\section{RESULTS AND DISCUSSION}

Based on the result profile of electrical resistivity survey for Line A (Figure 7), location with groundwater potential is at position $200 \mathrm{~m}$, with values ranging from 10-100 $\Omega \mathrm{m}$ resistivity. The depth of potential groundwater based on this profile began at approximately $20 \mathrm{~m}$ below ground level.

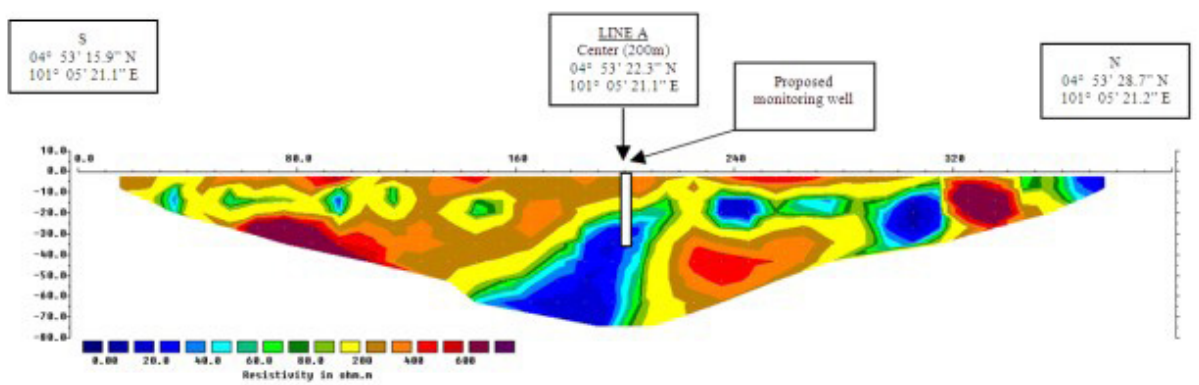

Figure 7: Palm oil mill survey line A (upgradient). 
Location with groundwater potential electrical resistivity survey for Line B (Figure 8 ) is at position $215 \mathrm{~m}$, with values ranging from 10-100 $\Omega \mathrm{m}$ resistivity. The depth of potential groundwater based on this profile began at approximately $10 \mathrm{~m}$ below ground level.

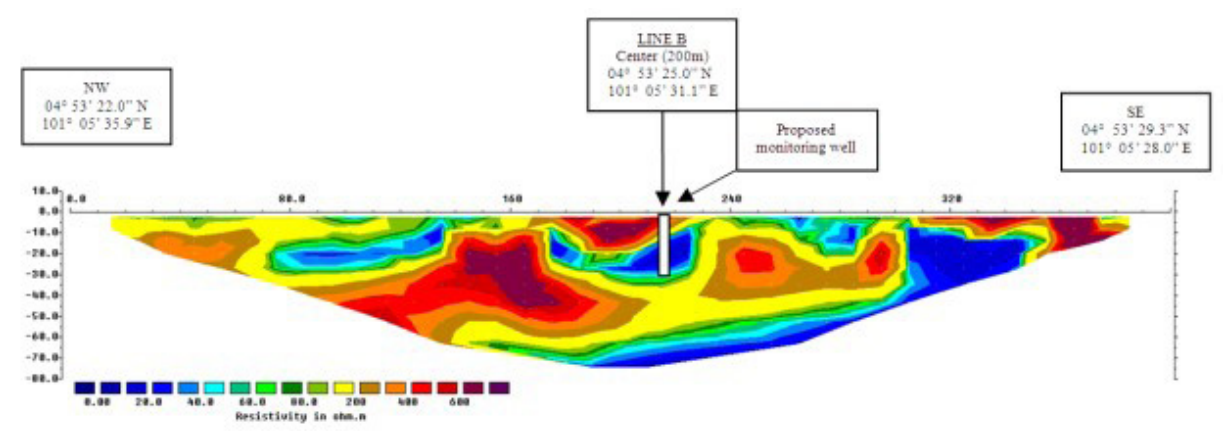

Figure 8: Palm oil mill survey line B (downgradient).

\subsection{Installation of Monitoring Wells and Sampling Points}

Based on the result profile of electrical resistivity survey, a total of 2 monitoring wells and 1 piezometers were constructed at the study sites. There were 4 surface water sampling points at the site. The coordinates of the monitoring wells, piezometers and surface water sampling points are shown in Table 4 below.

Table 3: Monitoring wells, piezometers and surface water sampling points coordinates.

\begin{tabular}{|c|c|c|c|c|}
\hline $\begin{array}{l}\text { Study } \\
\text { area }\end{array}$ & $\begin{array}{l}\text { Sampling } \\
\text { points }\end{array}$ & Coordinates & $\begin{array}{c}\text { Borehole } \\
\text { depth } \\
\text { (m.b.g.l) }\end{array}$ & $\begin{array}{c}\text { Reduce } \\
\text { level } \\
\text { (m.a.s.l) }\end{array}$ \\
\hline \multirow{7}{*}{$\begin{array}{l}\text { Palm oil } \\
\text { mill A }\end{array}$} & EMW1 & $04^{\circ} 53^{\prime} 24.8^{\prime \prime} \mathrm{N}, 101^{\circ} 05^{\prime} 31.0^{\prime \prime} \mathrm{E}(200 \mathrm{~m})$ & 30.00 & 76.00 \\
\hline & EMW2 & $04^{\circ} 53^{\prime} 21.9^{\prime \prime} \mathrm{N}, 101^{\circ} 05^{\prime} 21.2^{\prime \prime} \mathrm{E}(200 \mathrm{~m})$ & 20.00 & 102.00 \\
\hline & EPZ1 & $04^{\circ} 53^{\prime} 22.0^{\prime \prime} \mathrm{N}, 101^{\circ} 05^{\prime} 35.7^{\prime \prime} \mathrm{E}$ & 20.00 & 71.00 \\
\hline & ESW1 & $04^{\circ} 53^{\prime} 21.3^{\prime \prime} \mathrm{N}, 101^{\circ} 05^{\prime} 35.0^{\prime \prime} \mathrm{E}$ & - & - \\
\hline & ESW2 & $04^{\circ} 53^{\prime} 28.3^{\prime \prime} \mathrm{N}, 101^{\circ} 06^{\prime} 8.1^{\prime \prime} \mathrm{E}$ & - & - \\
\hline & ESW3 & $04^{\circ} 53^{\prime} 25.8^{\prime \prime} \mathrm{N}, 101^{\circ} 06^{\prime} 11.3^{\prime \prime} \mathrm{E}$ & - & - \\
\hline & ESW4 & $04^{\circ} 53^{\prime} 32.5^{\prime \prime} \mathrm{N}, 101^{\circ} 06^{\prime} 4.2^{\prime \prime} \mathrm{E}$ & - & - \\
\hline
\end{tabular}

The monitoring wells, piezometers and surface water sampling points maps of palm oil mill are shown in Figure 9. 


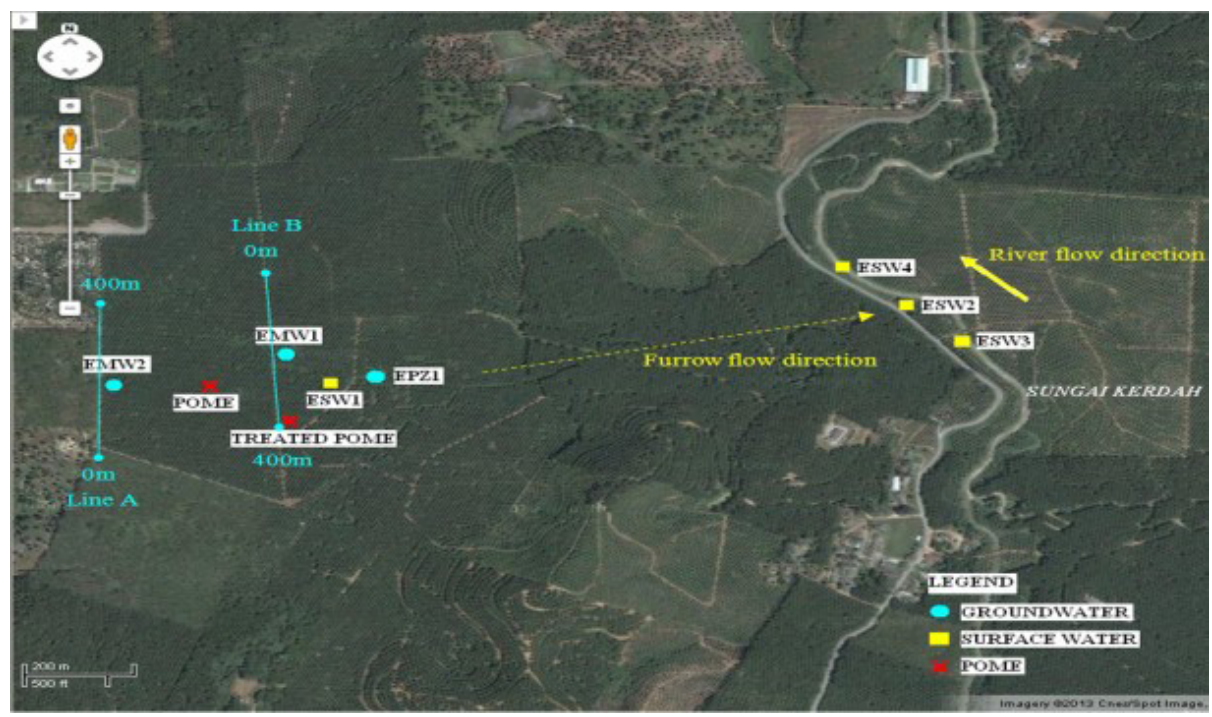

Figure 9: Palm oil mill A sampling locations.

The plot of $\delta^{2} \mathrm{H}-\mathrm{H}_{2} \mathrm{O}$ vs $\delta^{18} \mathrm{O}-\mathrm{H}_{2} \mathrm{O}$ for palm oil mill A is shown in Figure 10. This is in accordance with the Global Meteoric Water Line (GMWL) and the theoretical relationship between water bodies (Figure 11). However, the value for surface water was a bit depleted (located slightly below the GMWL) and this was anticipated as it is more subject to evaporative process compared to the groundwater. The raw POME and treated POME was found lying on the evaporation line with highly enriched (more positive) values of $\delta^{2} \mathrm{H}$ and $\delta^{18} \mathrm{O}$ compared to groundwater and surface water. This was also expected, as raw POME and treated POME were placed in ponds and thus were more subject to evaporation. Treated POME is relatively enriched compared to raw POME, due to longer residence time and biological processes in the ETP. All the surface water upstream (ESW1) showed no sign of mixing with neither raw POME nor treated POME as ESW1 was located quite distant from raw POME and treated POME in the $\delta^{2} \mathrm{H}-\mathrm{H}_{2} \mathrm{O}$ vs $\delta^{18} \mathrm{O}-\mathrm{H}_{2} \mathrm{O}$ plot. However, ESW1 was located exactly between groundwater and surface water in this plot, which may indicate an interaction between surface water and groundwater. This may be due to the groundwater is recharging the surface water (ESW1) in the vicinity of the furrow area. 


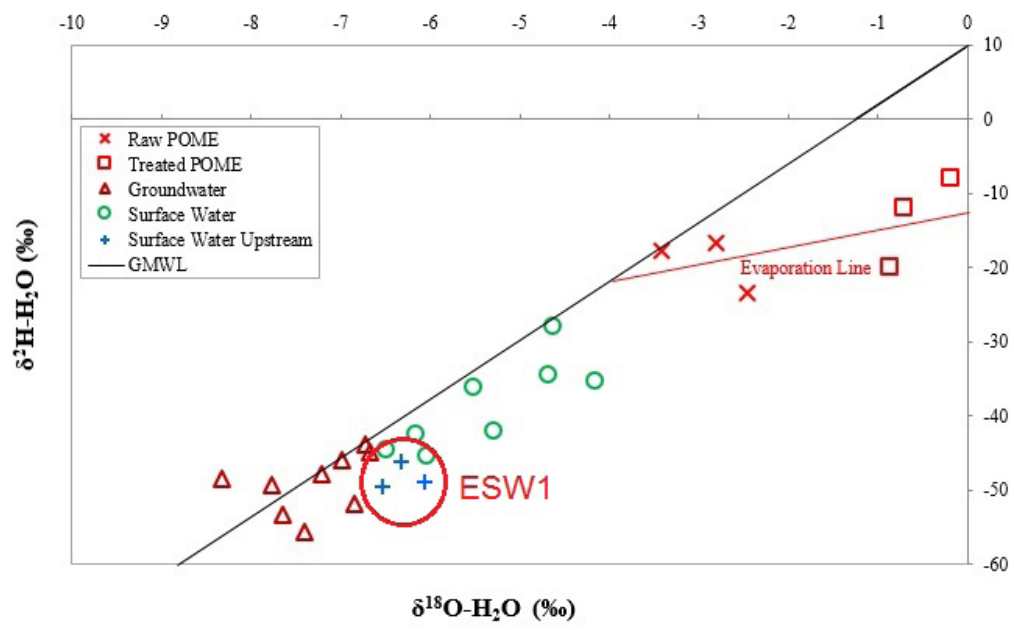

Figure 10: Plot of $\delta_{2} \mathrm{H}-\mathrm{H}^{2} \mathrm{O}$ vs $\delta_{18} \mathrm{O}-\mathrm{H}^{2} \mathrm{O}$ for palm oil mill A.

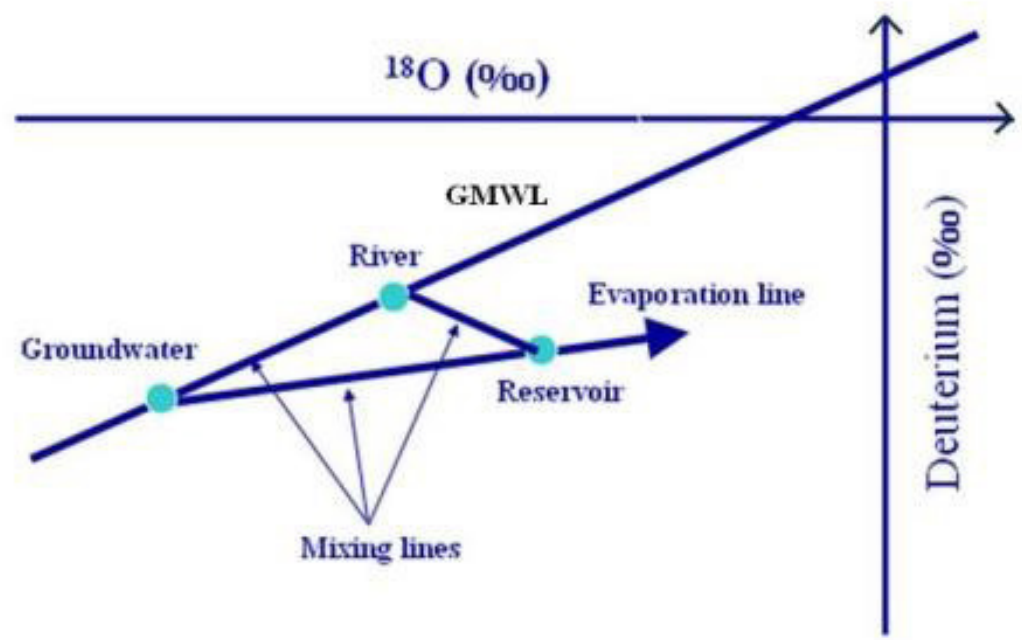

Figure 11: Theoretical $\delta_{2} \mathrm{H}$ and $\delta_{18} \mathrm{O}$ relationship - possible isotopic contrast between different types of water interacting in the vicinity of a reservoir. 


\section{CONCLUSION}

Stable isotopes technique has been applied in this study to determine the isotopic values of ${ }^{2} \mathrm{H}$ and ${ }^{18} \mathrm{O}$. Results suggested that individual isotopic fingerprints can be used distinctly to identify POME as a source of surface water and groundwater contamination in the study area. The highly enriched isotopic values of POME and treated POME associated with oil palm production processes and treatment in the ETP provide unique distinct isotopic composition for the POME and treated POME-affected waters resulted from the mixing process either in the surface water or groundwater.

\section{ACKNOWLEDGEMENTS}

This research has been supported by the Ministry of Science, Technology and Innovation (MOSTI), Malaysia under the ScienceFund grant. The project leader would like to thank 03-03-01-SF0103 ScienceFund project team members especially Mr. Kamaruzaman Mohamad@Mamat and Ms. Rohaimah Demanah for their help during the entire period of the study.

\section{REFERENCES}

1. Hackley, K. C., Liu, C. L. \& Coleman, D. D. (1996). Environmental isotope characteristic of landfill leachate and gases. Wiley Intersci., 34(5), 827-836, https://doi.org/10.1111/j.1745-6584.1996.tb02077.x.

2. Hosseini, S. E. \& Wahid, M. A. (2013). Feasibility study of biogas production and utilization as a source of renewable energy in Malaysia (A review). Renew. Sustain. Energy, 19, 454-462, https://doi.org/10.1016/j. rser.2012.11.008.

3. Sime Darby Plantation. (2014). Palm oil facts and figures. Retrieved from http://www.simedarbyplantation.com/upload/Palm-Oil.pdf on 22 February 2012.

4. Leaney, F. W. J. (2003). Using the direct absorption method to analyze ${ }^{14} \mathrm{C}$ in groundwater and samples containing inorganic carbon: Installation report and instruction manual. Published report for Commonwealth Scientific and Industrial Research Organisation (CSIRO).

5. Malaysian Palm Oil Board (MPOB). (2013). Overview of the Malaysian oil palm industry 2011. Retrieved from http://bepi.mpob.gov.my/images/ overview/Overview_of_Industry_2011.pdf on 22 February 2012. 
6. Mohd Tadza, A. R. et al. (2006). Application of isotope hydrology to determine the impact of leachate from Taiping municipal waste disposal site on the groundwater quality in Malaysia. Published report for Malaysia Institute for Nuclear Technology Research (MINT).

7. Ng, W. P. Q. et al. (2012). Waste-to-wealth: Green potential from palm biomass in Malaysia. J. Clean. Prod., 34, 57-65, https://doi.org/10.1016/j. jclepro.2012.04.004.

8. Rupani, P. F. et al. (2010). Review of current palm oil mill effluent (POME) treatment methods: Vermicomposting as a sustainable practice. World Appl. Sci. J., 11 (1), 70-81.

9. SERCON. (2007). Isotope ratio mass spectrometer (IRMS) operation manual. London: SERCON.

10. Tabatabaei, M. et al. (2010). Importance of the methanogenic archaea populations in anaerobic wastewater treatments (A review). Process Biochem., 45, 1214-1225, https://doi.org/10.1016/j.procbio.2010.05.017.

11. Wu, T. Y. et al. (2007). Palm oil mill effluent (POME) treatment and bioresources recovery using ultrafiltration membrane: Effect of pressure on membrane fouling. Biochem. Eng. J., 35, 309-317, https://doi.org/10.1016/j. bej.2007.01.029.

12. Wu, T. Y. et al. (2010). Pollution control technologies for the treatment of palm oil mill effluent (POME) through end-of-pipe processes. J. Environ. Manage., 91, 1467-1490, https://doi.org/10.1016/j.jenvman.2010.02.008.

13. Zhang, C., 2007. Fundamentals of environmental sampling and analysis. New Jersey: John Wiley \& Sons, https://doi.org/10.1002/0470120681. 